\title{
The Publications of the Royal Commission on Historical Manuscripts
}

\begin{abstract}
The Royal Commission on Historical Manuscripts publishes edited texts of manuscripts that are valuable primary sources for historical research. This article explains the rather complex arrangement of these publications and gives suggestions for locating them in libraries. Included is a list of indexes and bibliographies that are helpful in identifying relevant material in these reports.
\end{abstract}

I N 1869 QueEn Victoria APPOINTED the Royal Commission on Historical Manuscripts whose mission was to inquire as to the existence and location of privately owned manuscripts, records, and archives of all kinds which might have value for the study of history. The collections to be investigated were those belonging to both institutions and families and were known to contain “. . . Manuscripts and Papers of general Public Interest a knowledge of which would be of great utility in the illustration of History, Constitutional Law, Science and general Literature. ..."1 Although the existence of some of these collections was well known, many were either forgotten or neglected and were in danger of decay. The Royal Commission on Historical Manuscripts, created at a time of renewed interest in historical manuscripts, has devoted itself to its primary task of locating such muniments and bringing them to the attention of scholars through the publication of edited texts.

Some of the collections investigated by the commission had been assembled

Elliot S. Palais is chief bibliographer at the Arizona State University library, Tempe. by antiquaries and bibliophiles while others were simply the accumulated papers resulting from the business transactions of landed families. ${ }^{2}$ Nevertheless, all of them are valuable sources for historical research and the commission continues searching for them, assisting in their preservation, and making lists of the manuscripts so that they will be available for research. The commissioners offer advice to the owners on the repair and binding of papers and, with their consent, may arrange to have collections deposited in local or county record offices or archives, such as the Lincolnshire Archives Office.

Since the time of its appointment, the commission has reported on the manuscripts of over eight hundred private owners and corporate bodies, including boroughs, cathedrals, counties, parishes, and endowed institutions, such as colleges. All collections are located in Great Britain or Ireland. The commission does not concern itself with papers which are public records by virtue of the Public Records Act and which are kept in the Public Record Office in London.

The published reports or calendars of these collections now total over two hundred and fifty volumes and more are in preparation. The bulk of this 
material is concerned with British local, national, and colonial history, including a large amount of American colonial history. There is much information on any place in the world where the British had political, economic, or military interests. The reports also contain a great deal of biography and social history, chiefly concerning the peoples of Great Britain and Ireland. Many of the reports contain the text of papers and letters of landed families, such as the Cecil family, which contributed many statesmen to national affairs. The Salisbury (Cecil) papers are of great value for the study of Elizabethan and early Stuart England since they consist largely of state documents, despatches, memoranda, and correspondence.

The value of the reports as a source for research is suggested in the following statements. Richard A. Roberts, former secretary of the commission, wrote that "They often serve every purpose that an examination of the originals would fulfil, and even a better purpose, because the Report is much easier to study, and gives the important information, omitting all trivial and negligible matter. ..."3 Speaking before the Royal Historical Society, Roberts described the wealth of material in the reports and said: "If, in 1872, the Commissioners of that day could justifiably affirm, with some amount of pride in the work so far accomplished, 'it is not too much to say that there is scarcely an important historical event, certainly no period of English history, which has not received some elucidation from the operations of the Commission,' I venture to think that the statement is true in an infinitely greater degree at the present moment." 4 Over sixty years have passed since Roberts made that statement and it could be made with even greater force today.

Students of American history will also find source material in the reports. J. Franklin Jameson, director (19051928) of the Department of Historical
Research of the Carnegie Institution, wrote that "Many of the volumes are replete with information relating to American history, particularly of the colonial and Revolutionary periods. . . . The collection is a rich mine of knowledge for the American student, containing texts or summaries of uncounted documents inaccessible to him in his own country. ..." ${ }^{\text {s }}$

\section{General Description of the Reports}

The reports published by the Royal Commission on Historical Manuscripts are of two kinds: (1) The Commissioners' Reports to the Crown, and (2) the Inspectors' Reports to the Commissioners.

The Commissioners' Reports are formal reports of business transacted by the commission. They contain accounts of what the commissioners tried to accomplish and useful summary descriptions of the collections examined by the inspectors. They may be used as a rough guide to the contents of the Inspectors' Reports, which contain the source material needed by historians. Between 1870 and 1967, twenty-five Commissioners' Reports to the Crown were published.

The first nine of these Commissioners' Reports contained one or more appendices, bound in the same physical volume, consisting of the Inspectors' Reports on the manuscript collections they had examined. Since the aim in these early years (1870-1884) was to present a summary account of the year's work, the examination of the collections was superficial and the reports on individual collections were brief. These general surveys were intended to aid the commissioners in determining which collections deserved more elaborate treatment, such as that found in the later reports, in which many of the collections that had been briefly surveyed were given a supplementary and more systematic treatment. In these later reports, the manuscripts have been carefully exam- 
ined and calendared, i.e., listed in chronological order and either quoted in extenso or summarized.

When the Inspectors' Reports became lengthy and detailed calendars rather than preliminary surveys with the tenth report (1885), they were physically separated from the Commissioners' Reports to the Crown and were published as separate volumes. The Inspectors' Reports were officially regarded as appendices to the Commissioners' Reports until the fifteenth report, published in 1899. Since then, the Inspectors' Reports have been issued as separate publications, independent of the Commissioners' Reports to the Crown. They are usually identified by a short descriptive title or by the designation "Various Collections."

\section{Numbering AND DESCRIPTION OF THE REPORTS}

The Commissioners' Reports to the Crown are numbered consecutively from the first report of 1870 to the twenty-fifth report of 1967 . The Inspectors' Reports that were printed as appendices are identified by both the report number and the appendix number.

In order to simplify reference to the reports, each volume containing Inspectors' Reports has been given a serial number. Volumes relating entirely to one collection are grouped together under the same serial number. For example, the ten volumes describing the Duke of Portland's papers are collected as series 29 , numbers 1 to 10 , even though they were published at intervals between 1891 and 1931 .

Some volumes contain material on more than one collection, and in such cases it was not possible to assign one serial number to a collection. For example, the papers of the Earl of Denbigh are surveyed with other collections in series $3,5,6$ and 7 ; only series 68 relates exclusively to the Denbigh collection. Sectional List Number 17 lists all of the reports in serial number order. ${ }^{1}$ After each serial number, the report number or descriptive title appears in boldface. There is also an index by the name or descriptive title. Using this list, it is possible to locate the serial number of a report identified in a bibliography simply by its report number or descriptive title.

In order to avoid repetition of the long full titles in footnotes, the Royal Commission on Historical Manuscripts recommends use of the following system of brief references.

When reference is made to volumes relating to one collection only, quote the serial number, the descriptive title, and the page number, e.g.,

\section{HMC 53: Montagu: p.94.}

When reference is made to papers published in separate volumes over a period of years, the reference must include the volume or part number, e.g.,

HMC 29: Portland III: p.94.

References to volumes relating to several collections should also include the report number, e.g.,

\section{HMC 2: 3rd R.: Orlebar: p.275.}

The appendix number must be cited when a report was issued with a number of appendices, e.g.,

\section{HMC 27:12th R. IX: Beaufort: p.16}

(Historical Manuscripts Commission, Series 27; 12th report, appendix 9, Beaufort papers, page 16).

The Royal Commission adopted the practice of identifying and arranging the reports by serial number after a large number of volumes had been published. For this reason, some of the older guides and bibliographies will not identify the reports by their serial number, but by some combination of descriptive title, report number, or appendix number. It is necessary to read the instructions accompanying each bibliog- 
raphy in order to become familiar with the particular scheme of documentation used.

\section{Guides and Indexes to the Reports}

A. Guides Published by the Royal Commission

Great Britain. Historical Manuscripts Commission. A Guide to the Reports on Collections of Manuscripts of Private Families, Corporations and Institutions in Great Britain and Ireland Issued by the Royal Commissioners for Historical Manuscripts. London: H.M.S.O., 1914 1938. Part I:

Topographical Guide; Part II: Index of Persons. 3 volumes.

These indexes to places and persons are cumulations of the indexes included in each volume of the reports published from 1870 to 1911 . Reference is made to the volume only, not to the page number. These guides are included in the Microcard edition.

Great Britain. Historical Manuscripts Commission. Guide to the Reports of the Royal Commission on Historical Manuscripts, 19111957. London: H.M.S.O., 1966. 3 volumes.

Only the Index of Persons has been published. A Topographical index is in preparation.

B. Published Bibliographies Containing Reference to the Reports

1. General

Mullins, Edward Lindsay Carson. Texts and Calendars; an Analytical Guide to Serial Publications. London: Royal Historical Society, 1958.

Pages 61-90 contain full descriptions of the reports through series 81. The index provides references to names of the collections and to important subjects.
2. United States History

Andrews, Charles McLean. Guide to the Manuscript Materials for the History of the United States to 1783. Washington: Carnegie Institution, 1908.

Crick, Bernard R. A Guide to Manuscripts Relating to America in Great Britain and Ireland. London: Oxford University Press, 1961.

This volume, which includes references from Jameson's "Guide" (see below), is arranged by the location of the manuscripts and is indexed by subject.

Jameson, J. Franklin. "Guide to the Items Relating to American History in the Reports of the English Historical Manuscripts Commission and their Appendixes." In American Historical Association. Annual Report for the Year 1898. Washington: Government Printing Office, 1899. p.611-708.

The "Guide" provides references to items relating to the history of the United States and to those colonies which occupied any portion of the area now embraced in the United States, Newfoundland, Canada, Cuba, Puerto Rico, and the Philippine Islands. Addenda to 1927 are printed in the Cambridge History of the British Empire, I, 837 (see below).

\section{British History}

The Cambridge History of the British Empire. Volume 1. Cambridge: University Press, 1929.

On pages $837-44$, there are lists of manuscripts of special value for the study of colonial history. Several pages are quoted in full from Davenport's Materials for English Diplomatic History (see below) and there are some later references that supplement Davenport. 
Davenport, Frances G. Materials for English Diplomatic History, 1509 1783, Calendared in the Reports of the Historical Manuscripts Commission, with Reference to Similar Materials in the British Museum. In Great Britain. Royal Commission on Historical Manuscripts. Commissioners' Report 18, Appendix II. London: H.M.S.O., 1917. p.357-402.

Davies, Godfrey. Bibliography of British History: Stuart Period, 1603-1714. 2d ed. ed. by Mary F. Keeler. Oxford: Clarendon Press, 1970.

Grose, Clyde Leclare. A Select Bibliography of British History, 1660 1760. Chicago: University of Chicago Press, 1939.

Gross, Charles. The Sources and Literature of English History from the Earliest Times to About 1485. 2d ed. New York: Peter Smith, 1951.

Pargellis, Stanley M., and D. J. Medley. Bibliography of British History: the Eighteenth Century, 1714-1789. Oxford: Clarendon Press, 1951.

The bibliography includes a list of local records, special subjects, and travel diaries published in the reports.

Read, Conyers. Bibliography of British History: Tudor Period, 1485 1603. 2d ed. Oxford: Clarendon Press, 1959.

On pages 10-22, there is a list of reports under a few major subject headings. Read gives some indication of the value of the material and provides information on some of the collections that have been reprinted elsewhere.

Upton, Eleanor S. Guide to Sources of English History from 1603 to 1660 in Early Reports of the Roy- al Commission on Historical Manuscripts. $2 \mathrm{~d}$ ed. New York: Scarecrow Press, 1964.

This is an index to subjects other than persons and places and so serves as a supplement to the guides published by the commission.

\section{LOCATING THE REPORTS IN LIBRARIES}

Reports published up to and including 1920 appeared as Parliamentary $\mathrm{Pa}$ pers and bear Stationery Office code numbers, e.g., CD.5567 of 1911. These code numbers are given in Sectional List No. 17.

Some libraries have cataloged the reports separately, i.e., as calendars of individual collections. In such cases, the card catalog will contain a corporate entry and various added entries and subject cards. In the case of the Dartmouth (American) Papers, the following entries may be found:

Gt. Britain. Historical Manuscripts Commission. The Manuscripts of the Earl of Dartmouth.

Dartmouth, William Walter Legge, 5th earl of.

Gt. Britain-History-Sources.

U.S.-History-Sources.

Added entries for the editors of the various volumes.

Perhaps the most convenient method of arrangement is by the serial number assigned by the Royal Commission. (The Microcard edition, which includes all reports published from 1870 to 1946, employs this method.) When the serial number arrangement is used, the Commissioners' Reports are in numerical order, starting with number ten, followed by the Inspectors' Reports in serial number order. Each of the first nine Commissioners' Reports is bound in the same physical volume with the appendices containing Inspectors' Reports. Because all volumes containing Inspectors' Reports have been assigned a serial 
number, the first nine Commissioners' Reports must be shelved in serial number order with the Inspectors' Reports with which they are bound. For example, the eighth report is found in Series 7, part I, with Appendix I, which is the Inspectors' Report. Starting with the tenth report, the Commissioners' Reports were published as separate volumes and therefore may be arranged in a separate series in numerical order.

As new Inspectors' Reports are published, they are assigned the appropriate serial number and a volume or part number. For example, new additions to the Salisbury (Cecil) Papers are assigned to series 9 and are given a volume number to keep that series in chronological sequence. Use the latest edition of Sectional List No. 17 for a complete list of all reports arranged in serial number order. For all collections arranged in serial number order, this list is an indispensable finding guide.

\section{The Modern Program of the Commission}

Recent activities of the Royal Commission on Historical Manuscripts include maintenance of the National Register of Archives; the Joint Publication Program; the continued provision of calendars, edited texts, and other aids to research; proffering advice and assistance to owners and users of manuscripts; and cooperation with other or- ganizations in the same field.

The National Register of Archives, located in Quality Court, Chancery Lane, London, was created as a branch of the Royal Commission in 1945 to aid in the location, description, and preservation of manuscripts. It has become a central guide to the primary material for historical research in the United Kingdom because of the special indexes it maintains.

The Joint Publication Program, established in 1958, provides that volumes prepared by local or national historical societies may be printed by the Stationery Office as publications of the Roval Commission.

The reports published by the Royal Commission so far have dealt with events before 1801. A new series will start with the papers of nineteenth-century prime ministers. A survey has been published and the first collections chosen for publication are the autobiographical writings of Gladstone, the political papers of the Duke of Wellington, and the Palmerston Papers. ${ }^{6}$ The Royal Commission is also expanding its program to cover the papers of British scientists and is preparing a guide to the location and content of such collections. As the Royal Commission discovers more primary material, librarians must be alert to provide their patrons with all of the published material designed to further historical research.

\section{REFERENCES}

1. Great Britain, Royal Commission on Historical Manuscripts, Publications of the Royal Commission on Historical Manuscripts, Sectional List Number 17 (London: H.M.S.O., $1970)$, p.1. This list is revised periodically.

2. Great Britain, Royal Commission on Historical Manuscripts, Manuscripts and Men (London: H.M.S.O., 1969).

3. Richard A. Roberts, The Reports of the Historical MSS. Commission, Helps for Students of History Number 22 (New York: Macmil- lan, 1920), p.10.

4. Richard A. Roberts, "Concerning the Historical Manuscripts Commission," Royal Historical Society Transactions, Third Series 4: 77 (1910).

5. American Historical Association, Annual Report for the Year 1898 (Washington: Government Printing Office, 1899), p.570-71.

6. John Brooke, ed., The Prime Ministers' Papers, 1801-1902 (London: H.M.S.O., 1968). 